Published by Al-Nahrain College of Medicine P-ISSN 1681-6579

E-ISSN 2224-4719

Email: iraqijms@colmed-alnahrain.edu.iq

http://www.colmed-alnahrain.edu.iq

http://www.iraqijms.net

\title{
Detection of Hepatitis C Virus in Iraqi Patients with Oral Lichen Planus
}

\author{
Heba F. Hassan ${ }^{1} P h D$, Ahmed A. Abbas ${ }^{2} P h D$, Abbas M. Ahmed ${ }^{3} P h D$, Sabeeh A. Hassan ${ }^{4} M S C$ \\ ${ }^{1}$ Dept. of Basic Sciences, College of Dentistry, University of Baghdad, Baghdad, Iraq, ${ }^{2}$ Dept. of Microbiology, College of \\ Medicine, Al-Nahrain University, Baghdad, Iraq, ${ }^{3}$ Central Public Health Laboratories, Baghdad, Iraq, Dept. of \\ Dermatology and Venereology, College of Medicine, University of Baghdad, Baghdad, Iraq
}

\begin{abstract}
Background Oral Lichen planus (OLP) is chronic mucocutaneous disorder with or without involvement skin, of unknown etiology. Lichen planus (LP) is T-cell-mediated chronic inflammatory disease of the stratified squamous epithelium. It can affect oral mucosa, skin, esophagus, nasal mucosa, larynx, genitalia, urinary tract, hair follicles and the eyes. Latterly has been focused on presence association between OLP and hepatitis C virus (HCV) infection, but this relation is not stable, since the prevalence of this virus in patients varies depended on studies, ranging from $0 \%$ to $67.8 \%$.

Objective This study was established to investigate the relationship between the OLP and HCV infection in Iraq and to detect the virus by Real-time polymerase chain reaction (RT-PCR).

Methods Blood samples were collected from 62 patients with OLP and controls to detect the HCV in those patients by using one step anti-HCV test, ELISA test and RT-PCR.

Results The current study revealed that the early detection of HCV by one step Anti-HCV for all OLP patients was negative and by ELISA showed that four patients (12.5\%) of OLP were positive for HCV. While using RT-PCR found that only one patient (3.1\%) was positive for the presence of the virus.

Conclusion There was not relationship found between OLP and HCV infection in Iraqi patients.

Keywords Oral lichen planus, HCV, RT-PCR, ELISA

DOI: $10.22578 / \mathrm{IJMS}$.14.4.4
\end{abstract}

List of abbreviation: ELISA = Enzyme linked immunosorbant assay, $\mathrm{HCV}=$ Hepatitis C virus, LP = Lichen planus, OLP = Oral lichen planus, $\mathrm{RT}-\mathrm{PCR}=$ Real-time polymerase chain reaction, $\mathrm{RNA}=$ Ribonucleic acid

\section{Introduction}

$\mathrm{O}$ ral lichen planus (OLP) considered as a disease of stratified squamous epithelia (1). The clinical estimate of the oral lesions is depended on the six clinical shapes: atrophic, bullous, erosive, papular, plaque and reticular ${ }^{(2)}$ that usually cause bilateral white striations, papules, or plaques on the buccal mucosa, tongue, and gingiva. Erythema, erosions, and blisters may or may not be present ${ }^{(3)}$. OLP occurs more frequently than the cutaneous form and tends to be more persistent and more resistant to treatment, oral lesion accompanies, precedes or follows cutaneous lesion ${ }^{(4)}$. Theoretically some genetic change may facilitate the development of OLP in a subgroup of patients with hepatitis $C$ results to geographical heterogeneity ${ }^{(5)}$ or epitopic similarities between hepatitis $C$ virus (HCV) and keratinocytes could explain the relationship between lichen planus (LP) and $\mathrm{HCV}$, but this could not be demonstrated in any studies ${ }^{(6)}$. The first case of LP relationship to $\mathrm{HCV}$ was reported from France in $1991^{(7)}$. The ratio of $\mathrm{HCV}$ infection in patients with OLP appear to be high in Japan, Italy and Brazil (8) and not detected in British, Nordic countries, and Germany. Whereas the results in USA, 
India and Saudia Arabia are rescaled Although the pathogenesis of OLP is unknown and several studies have been suggesting its association with chronic hepatitis $C^{(6,10)}$ but the correlation of OLP with HCV infection remains controversy. After acute HCV infection, the ratio of patients who may stay chronically infected is estimated to be as high (85-90\%). A large proportion of these chronically infected patients without symptom for HCV infection and becomes carriers. OLP in certain individuals can be used as a marker for diagnosis of HCV infection in asymptomatic patients, leading to early therapy and best prognosis ${ }^{(11)}$. It has been estimated that HCVinfected patients have at least twice the risk of progress LP than the general population. The reports of correlation the LP with HCV suggest marked geographic differences ${ }^{(12)}$. During the past years, different studies from Brazil, Iran, Israel, Saudi Arabia, Thailand, Taiwan and Turkey showed statistically significant association between presence of OLP and HCV infection ${ }^{(13)}$, another two Italian studies, two Indian studies, two Iranian studies, one Brazilian study, one Turkish study, one Serbian study and one from UK were not able to find any correlation between chronic HCV infection and OLP ${ }^{(13)}$. There are no study present between oral lichen planus and HCV in Iraqi patients.

This study was established to investigate the relationship between the OLP and HCV infection in Iraq and to detect the virus by Elisa test and Real-time polymerase chain reaction (RT-PCR)

\section{Methods}

\section{Patients and control groups}

Thirty-two patients attending the Dermatological Outpatient Clinic at Medical City in Baghdad from June 2014 till February 2015, were eligible in this study. A specialist physician based on the clinical pictures diagnosed them all. Excluded criteria: patients without chronic periodontitis, gingivitis and without systemic diseases. Current study included thirty apparently healthy volunteers were considered as control group, their age and gender matched with patients group, received no treatment with no complaint of other chronic or systemic diseases, no history or clinic evidence of malignant disease.

\section{Blood Samples}

$3 \mathrm{ml}$ of Blood was collected from each patient and control, put in clot activator tubes for serum separation by centrifugation at $2600 \mathrm{~g}$ for 15 minutes at $4^{\circ} \mathrm{C}$, and then stored at $-80^{\circ} \mathrm{C}$. The Ethical Committee of College of Medicine, Al-Nahrain University approved this study, and all samples were obtained with informed consent in accordance with Medical City in Baghdad declaration.

\section{Detection of Antibodies to HCV infection:}

One-step Rapid test: One-step Anti-HCV test is a rapid direct binding test for the qualitative detection of anti HCV antibody in serum (Blue Cross Bio-Medical, Beijing, China).

Detection of antibodies (both IgG and IgM) of HCV by ELISA: (CTK BIOTECH, USA, E0511).

\section{Detection of RNA of HCV by RT-PCR:}

Viral RNA extraction: The ExiPrepTM (BIONEER, Korea, K3525) automated viral RNA Kits are suitable to extract of viral RNA from serum samples.

Detection of HCV by RT-PCR: The artus HCV RG RT-PCR Kit (QIAGEN, Germany, 4518265) constitutes a ready to use system for the detection of HCV RNA using polymerase chain reaction (PCR) on rotor-gene $Q$ instruments.

The statistical analysis of this prospective study performed with the statistical package for social sciences (SPSS) 21.0 and Microsoft Excel 2013. Chi-square test used to describe the association of these data. Numerical data were described as mean, standard deviation of mean. Mann-Whitney test used for comparison between two groups while kruskal wall is test used for comparison among more than two 
groups. The lower level of accepted statistical significant difference is bellow or equal to 0.05 .

\section{Results}

Distribution of patients and control group according to age was listed in table (1), most patients $(43.8 \%)$ were at age group ( $>50$ years), however, there is no significant difference between this group and other age groups $(p=0.102)$. There was female predominance among patients, as 20 (62.5\%) of OLP patients were females, while only 12 (37.5\%) of patients were males figure (1).

While the distribution of patients according to clinical types the OLP patients were classified to three subgroups, (14 patients were reticular form and 11 of patients were with erosive form while 7 patients with plaque like form). In addition, there were no significant differences ( $p>0.05)$ in types of disease according to gender, table (2).

Table 1. Distribution of OLP patients and healthy controls according the age groups

\begin{tabular}{ccccc}
\hline \multirow{2}{*}{ Age groups } & \multicolumn{2}{c}{ Study groups } & Total \\
& & $\begin{array}{c}\text { Healthy } \\
\text { control }\end{array}$ & OLP & \\
\hline \multirow{2}{*}{$\mathbf{2 0 - 3 0}$ years } & Count & 2 & 4 & 6 \\
& $\%$ & $6.7 \%$ & $12.5 \%$ & $9.7 \%$ \\
\multirow{2}{*}{$\mathbf{3 1 - 4 0}$ years } & Count & 11 & 4 & 15 \\
& $\%$ & $36.7 \%$ & $12.5 \%$ & $24.2 \%$ \\
\multirow{2}{*}{$\mathbf{4 1 - 5 0}$ years } & Count & 10 & 10 & 20 \\
& $\%$ & $33.3 \%$ & $31.3 \%$ & $32.3 \%$ \\
$>\mathbf{5 0}$ years & Count & 7 & 14 & 21 \\
& $\%$ & $23.3 \%$ & $43.8 \%$ & $33.9 \%$ \\
\hline \multirow{2}{*}{ Total } & Count & 30 & 32 & 62 \\
& $\%$ & $100.0 \%$ & $100.0 \%$ & $100.0 \%$ \\
\hline p value & & \multicolumn{3}{c}{$0.102^{\mathrm{NS}}$} \\
\hline
\end{tabular}

NS: non-significant

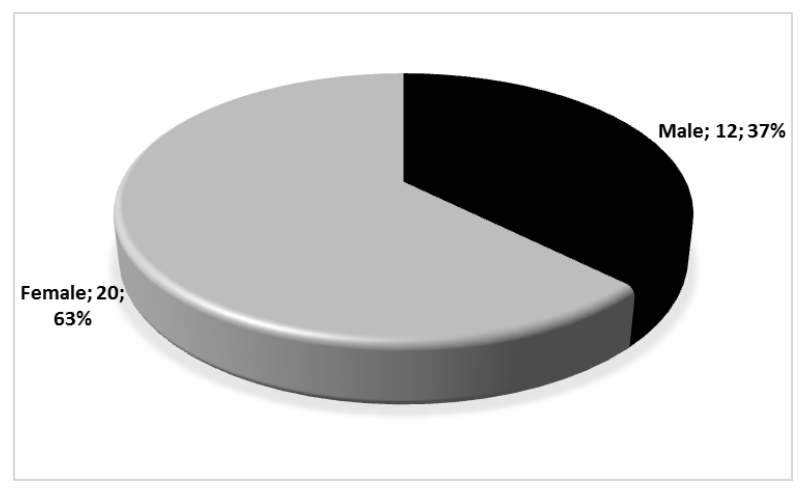

Figure 1. Distribution of OLP patients according to gender 
Table 2. Distribution of OLP patients according the clinical types and gender

\begin{tabular}{ccccccccc}
\hline & & Erosive & $\%$ & $\begin{array}{c}\text { Plaque } \\
\text { like }\end{array}$ & $\%$ & Reticular & $\%$ & p value \\
\hline \multirow{2}{*}{ Gender } & Male & 2 & 18.18 & 2 & 28.57 & 8 & 57.14 & \multirow{2}{*}{$0.116^{\text {NS }}$} \\
& Female & 9 & 81.82 & 5 & 71.43 & 6 & 42.86 & \\
\hline
\end{tabular}

NS: non-significant

\section{Detection of HCV}

One-step Anti-HCV: The primary detection (serological screening) of HCV by one step AntiHCV strips showed no antibodies against this virus neither in serum of OLP patients nor in serum of healthy controls as clearly shown in table (3).

Table 3. Anti-HCV serological screening by one-step Anti-HCV strips in OLP patients and healthy control

\begin{tabular}{cccccc}
\hline & & \multicolumn{3}{c}{ Study groups } & \multirow{2}{*}{ Total } \\
& & & Healthy control & OLP & \\
\hline \multirow{3}{*}{$\begin{array}{c}\text { One-step } \\
\text { Nnti-HCV }\end{array}$} & \multirow{2}{*}{ Negative } & Count & 30 & 32 & 62 \\
& & $\%$ & 100 & 100 & 100 \\
& Positive & Count & 0 & 0 & 0 \\
& $\%$ & 0.0 & 0.0 & 0.0 \\
\hline \multirow{2}{*}{ Total } & Count & 30 & 32 & 62 \\
& $\%$ & 100 & 100 & 100 \\
\hline
\end{tabular}

ELISA: The current results revealed that only four patients (12.5\%) of OLP were positive to anti-HCV Ab, whereas 28 (87.5\%) of patients were negative to anti-HCV Ab. Moreover, there were no significant differences $(p>0.05)$ in percentages of $\mathrm{Ab}$ between patients and control group, table (4). There was no significant differences ( $p>0.05)$ in mean serum level of anti-HCV Abs among three types of OLP, as shown in table (5).

Table 4. Anti-HCV screening by Elisa in OLP patients and healthy control

\begin{tabular}{|c|c|c|c|c|c|}
\hline & & & \multicolumn{2}{|c|}{ Study groups } & \multirow{2}{*}{ Total } \\
\hline & & & Healthy control & OLP & \\
\hline \multirow{4}{*}{ ELISA } & \multirow{2}{*}{ Negative } & Count & 30 & 28 & 58 \\
\hline & & $\%$ & 100 & 87.5 & 93.5 \\
\hline & \multirow{2}{*}{ Positive } & Count & 0 & 4 & 0 \\
\hline & & $\%$ & 0.0 & 12.5 & 6.5 \\
\hline \multirow{2}{*}{\multicolumn{2}{|c|}{ Total }} & Count & 30 & 32 & 62 \\
\hline & & $\%$ & 100 & 100 & 100 \\
\hline \multicolumn{3}{|c|}{ p value } & $0.064^{\mathrm{NS}}$ & & \\
\hline
\end{tabular}

NS: non-significant 
Table 5. Serum level of anti-HCV Abs according to clinical types of OLP

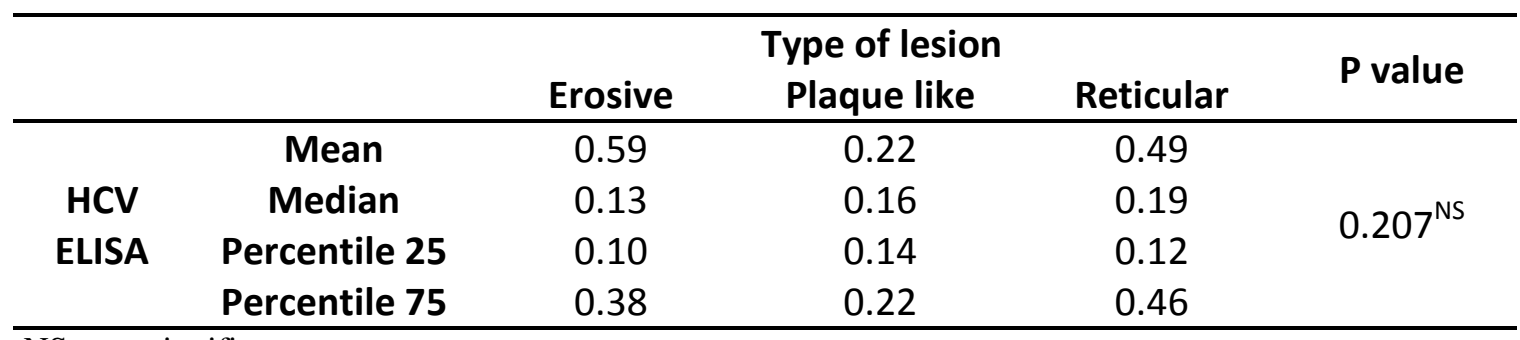

NS: non-significant

RT-PCR: The concentration and purity of nucleic acid samples has been measured by nanodrop, and only those samples with a purity ranged from 1.80 to 2.0 have been enrolled in this study. Only one patient (3.1\%) of 32 OLP patients was positive for HCV and the virus was not detected in control group figure (2\&3), table (6). It is worthy to mention that through this work not relationship found between HCV infection, which detected by RT-PCR and clinical types of OLP with $p$-value (0.373), table (7).

Table 6. Detection of HCV-RNA by RT-PCR in OLP patients and healthy controls

\begin{tabular}{|c|c|c|c|c|c|}
\hline & & \multicolumn{2}{|c|}{ Study groups } & \multirow{2}{*}{ Total } \\
\hline & & & Healthy control & OLP & \\
\hline \multirow{4}{*}{$\begin{array}{c}\text { HCV RT- } \\
\text { PCR }\end{array}$} & \multirow{2}{*}{ Negative } & Count & 30 & 31 & 61 \\
\hline & & $\%$ & 100 & 96.9 & 98.4 \\
\hline & \multirow{2}{*}{ Positive } & Count & 0 & 1 & 1 \\
\hline & & $\%$ & 0.0 & 3.1 & 1.6 \\
\hline \multirow{2}{*}{\multicolumn{2}{|c|}{ Total }} & Count & 30 & 32 & 62 \\
\hline & & $\%$ & 100 & 100 & 100 \\
\hline \multicolumn{2}{|c|}{$p$ value } & & & $516^{\mathrm{NS}}$ & \\
\hline
\end{tabular}

NS: non-significant

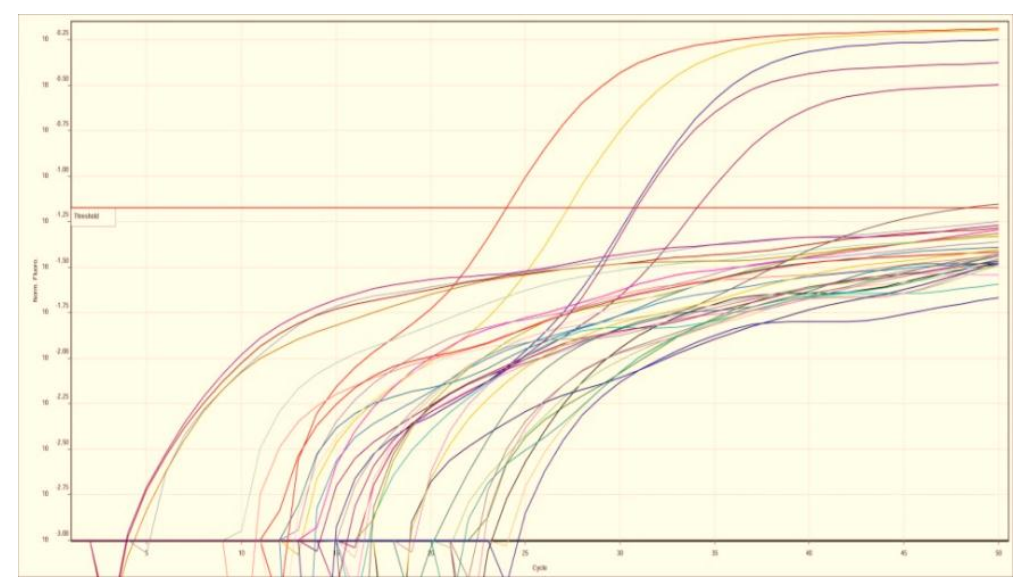

Figure 2. Detection of HCV infection in OLP patients 
Iraqi JMS 2016; Vol. 14(4)

Table 7. Relationship between clinical types of OLP with RT-PCR in HCV infection

\begin{tabular}{ccccccccc}
\hline & & Erosive & $\%$ & $\begin{array}{c}\text { plaque } \\
\text { like }\end{array}$ & $\%$ & reticular & $\%$ & p value \\
\hline HCV RT- & Negative & 10 & 90.91 & 7 & 100 & 14 & 100 & $0.373^{\text {NS }}$ \\
PCR & Positive & 1 & 9.09 & 0 & 0.00 & 0 & 0.00 & \\
\hline
\end{tabular}

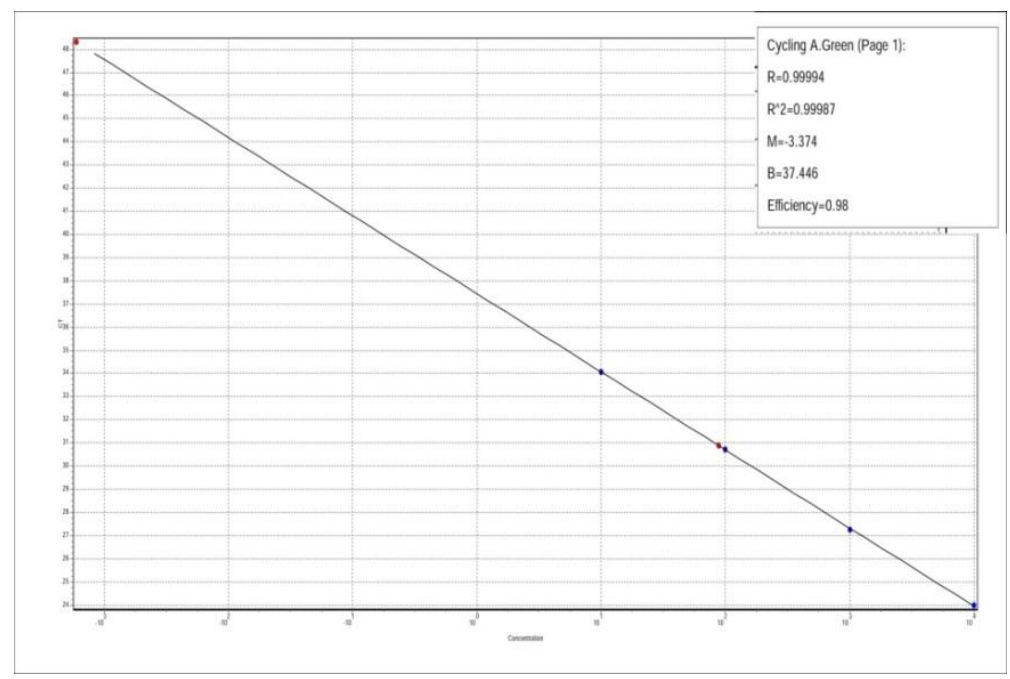

Figure 3. Standard curve of one positive sample in OLP patients with 4 standard positive controls (cyclic green)

\section{Discussion}

It is well known that OLP is a chronic inflammatory oral mucosal disease of unknown etiology; however, environmental and genetic factors are known to be involved in the development of this disease ${ }^{(14)}$. OLP has been reported as a complication of chronic HCV infection, and found that HCV-infected patients have at least twice the risk of developing OLP than the general population ${ }^{(12)}$. The present result showed that the OLP is more prevalent in patients with age more than 50 years with mean age (48.16) and this result is consistent with other study reported by Munde et al. ${ }^{(15)}$. Also the current results denoted a predominance of OLP among females than males which is comparable with other study conducted by $\mathrm{Yu}$ et al., who indicated that LP occurs more commonly in females ${ }^{(16)}$. The ratio of female to male was $2: 1$ and this ratio is agreement with other broad results in Iran ${ }^{(17)}$,
Saudi Arabia ${ }^{(18)}$, Turkey ${ }^{(19)}$ and in India ${ }^{(10)}$. The higher incidence in females may be referred to the hormonal differences between them and in part, their effects on the immune system. Those hormones make the females tend to mount more robust immune Th2 responses and may enhance the development of autoimmune disease ${ }^{(20)}$. In the present study, the reticular type was with highest frequency among patients and this finding agreement with previous reports which suggest that the reticular types was predominance types in OLP $(10,12,14)$. Although the pathogenesis of OLP is unknown, it is recognized as a T-cell-mediated immune disease, and several studies have been suggesting its association with chronic hepatitis $C^{(6,10)}$. The relationship between the HCV and OLP remains a controversial subject ${ }^{(10)}$. Mokni et al. in 1991 was the first found the presence of association between OLP and chronic liver disease in France ${ }^{(21)}$. On the other hand, 
Lavanya et al. 2011 mentioned that epidemiological evidences strongly suggest that HCV may be an etiologic factor in OLP ${ }^{(22)}$. The virus RNA was present in saliva, serum, skin lesions and oral tissues of involved HCV patients, this can suggest a cause-effect relationship between LP and $\mathrm{HCV}^{(23,24)}$. Several studies showed $15-35 \%$ of OLP patients have hepatic disease or disorders ${ }^{(25)}$. Halawani et al. 2010 showed that among 51 patients with OLP in Saudia Arabia, 5 (9.8\%) were anti-HCV positive, of which 2 (3.9\%) were HCV-RNA-PCR positive ${ }^{(25)}$. Similarly, El-Rifaei and colleagues take serum from 34 patients with OLP and found that 5 out of $34(14.70 \%)$ were positive to HCV infection ${ }^{(18)}$. Many studies showed no correlation between chronic HCV infection and OLP ${ }^{(10,12,17,26-28)}$. Gerayli et al. showed that there is no correlation between OLP and HCV in Iranian patients ${ }^{(24)}$, in the Mashhad ${ }^{(25)}$ and in Tabriz ${ }^{(29)}$. Anyway, Strak pointed out to that the prevalence of HCV antibodies in patients with OLP was found to be significantly higher than that in the control group in Iran, Jordan, Kingdom of Saudi Arabia and Turkey ${ }^{(30)}$. In Japan, where the prevalence of HCV infection was the highest in the country, which observed that $62 \%$ of the patients were with LP ${ }^{(31)}$. Also another study showed the prevalence of antiHCV and HCV RNA in Japanese patients were $67.80 \%$ (40/59) and 59.32\% (35/59), respectively in OLP ${ }^{(32)}$. Of all 232 Chinese OLP patients, the antibody of HCV infection was detected positive in 4 patients $(1.72 \%)$ using ELISA ${ }^{(33)}$. In India, only two studies proving presence relationships between OLP and HCV ${ }^{(34,35)}$. The current study revealed that the early detection of HCV infection in OLP patients.

The present study concluded that there was no relationship found between OLP and HCV infection in Iraqi patients.

\section{Acknowledgments}

I would like to express my gratitude to the patients and control subjects that participate in this study.

\section{Author contribution}

Dr. Hassan H.: collection of samples, data and writing the draft of the manuscript. Dr. Abbas: supervised data collection, study design and revising the manuscript. Dr. Ahmed helped in RT-PCR technique. Dr. Hassan S. helped in diagnosis of OLP patients.

\section{Conflict of interest}

The authors declare no conflict of interest.

\section{Funding}

Funding only from Dr. Heba F. Hassan.

\section{References}

1. Gangeshetty N, Kumar BP. Oral lichen planus: Etiology, pathogenesis, diagnosis, and management. World J Stomatol. 2015; 4(1): 12-21.

2. Boorghani $M$, Gholizadeh $N$, Zenouz $A T$, et al. Oral lichen planus: Clinical features, etiology, treatment and management; a review of literature. J Dent Res Dent Clin Dent Prospect. 2010; 4(1): 3-9.

3. Neville $W$, Douglas $D$, Carl $M$, et al. Oral maxillofacial pathology. $3^{\text {rd }}$ ed. Rio de Janeiro: Saunders; 2009. p. 784.

4. Mallaoglu N. Oral lichen planus. Br J Oral Maxillofac. Surg. 2000; 38: 370-7.

5. Farhi D, Dupin N. Pathophysiology, etiologic factors, and clinical management of oral lichen planus, part I: facts and controversies. Clin Dermatol. 2010; 28: 1008.

6. Scully C, Carrozzo M. Oral mucosal disease: Lichen planus. Br J Oral Maxillofac. Surg. 2008; 46: 15-21.

7. Akhtar J, Shahid M, Iqbal J, et al. Morphological patterns of lichen planus in patients with antihepatitis C antibodies. J Pakistan Ass Dermatol. 2007; 17: 225-30.

8. Shengyuan L, Songpo $Y$, Wen $W$, et al. Hepatitis C virus and lichen planus: a reciprocal assotiation determined by a meta-analysis. Arch Dermatol. 2009; 145: 1040-7.

9. Shekar C, Ganesan S. Oral lichen planus: Review. J Dent Sci Res. 2011; 2(1): 62-87.

10. Patil S, Khandelwal S, Rahman $F$, et al. Epidemiological relationship of oral lichen planus to hepatitis $C$ Virus in an Indian population. OHDM. 2012; 11(4): 199-205.

11. Hakkou F, Chbicheb S, Essaid EW, et al. Oral lichen planus and hepatitis $C$ virus infection: An epidemiological study of 149 cases. Int J Odontostomat. 2012; 6(2): 163-8.

12. Jayavelu $P$, Sambandan T. Prevalence of hepatitis $C$ and hepatitis $B$ virus infection(s) in patients with oral 
lichen planus. J Pharm Bioallied Sci. 2012; 4(Suppl 2): S397-405.

13. Mahboobi N, Agha-Hosseini F, Lankarani KB. Hepatitis $C$ virus and lichen planus: The real association. Hepat Mon. 2010; 10(3): 161-4.

14. Gupta SB, Chaudhari ND, Gupta A, et al. Lichen planus - An update. Int J Pharm Biomed Sci. 2013; 4(2), 59-65.

15. Munde A, Karle $R$, Wankhede $P$, et al. Demographic and clinical profile of oral lichen planus: $A$ retrospective study. Contemp Clin Dentist. 2013; 4(2): 181-5.

16. Yu TC, Kelly SC, Weinberg JM, et al. Isolated lichen planus of the lower lip. Cutis; Cutaneous medicine for the practitioner. 2003; 71(3): 210-2.

17. Ghodsi SZ, Daneshpazhooh M, Shahi M, et al. Lichen planus and hepatitis C: a case-control study. BMC Dermatol. 2004; 4. DOI: 10.1186/1471-5945-4-6.

18. El-Rifaei A, Fathalla S, Al-Sheikh I, et al. The prevalence of indices of hepatitis C and B infection, and elevated aminotransferase enzymes in patients with oral lichen planus (OLP) in eastern Saudi Arabia. J Family Community Med. 1998; 5(2): 39-43.

19. Denli YG, Durdu M, Karakas M. Diabetes and hepatitis frequency in 140 lichen planus cases in Cukurova region. J Dermatol. 2004; 31: 293-8.

20. Kindt TJ, Goldsby RA, Osborne BA. Kuby immunology. $6^{\text {th }}$ ed. New York: WH Freeman and Company; 2007. p. 408-11.

21. Mokni $M$, Rybojad $M$, Puppin $D$, et al. Lichen planus and hepatitis C virus. J Am Acad Dermatol. 1991; 24: 792. [PMID: 1651354 DOI: 10.1016/ S01909622(08)80376-3].

22. Lavanya $N$, Jayanthi $P$, Rao UK, et al. Oral lichen planus: An update on pathogenesis and treatment. J Oral Maxillofac Pathol. 2011; 15: 127-32 [PMID: 22529568 DOI: 10.4103/0973-029X.84474.

23. Maticic $M$. Hepatitis $C$ virus infection: the dermatological perspective. Acta Dermatovenerol Alp Pannonica Adriat. 2003; 12(1): 19-27.

24. Gerayli S, Meshkat Z, Pasdar A, et al. The association between oral lichen planus and hepatitis $C$ virus infection; A report from northeast of Iran Jundishapur. J Microbiol. 2015; 8(4): e16741.

25. Halawani $M$, Balbisi A, Alotaibi $H$, et al. The prevalence of HCV antibodies in skin disease patients in Saudi Arabia Saudi Pharmaceutical Journal. 2010; 18, 35-9.
26. Roy KM, Dickson EM, Staines KS, et al. Hepatitis C virus and oral lichen planus/lichenoid reactions: Lack of evidence for an association. Clinical Laboratory. 2000; 46: 251-4.

27. Ali $A A$, Suresh CS. Oral lichen planus in relation to transaminase levels and hepatitis $C$ virus. J Oral Pathol Med. 2007; 36: 604-8.

28. Mohan KP, Jois HS, Aallikerimath $S$, et al. Oral lichen planus as an extra-hepatic manifestation of viral hepatitis-evaluation in Indian subpopulation. J Clin Diag Resh. 2013; 7(9): 2068-9.

29. Zenouz AT, Mehdipour M, Gholizadeh N, et al. Evaluation of relationship between lichen planus and HCV antibody. J Dent Res Dent Clin Dent Prospect. 2010; 4(1): 10-3.

30. Strak S, Al-Hamdi K, Alabbood M. A study of lichen planus and its association with hepatitis $C$ infection. J Taibah Uni Medil Sci. 2015; 10(2): 222-6.

31. Nagao $Y$, Sata $M$, Tanikawa $K$ et al. Lichen planus and hepatitis $C$ virus in the northern Kyushu region of Japan. Eur J Clin Invest. 1995; 25: 910-4.

32. Nagao $Y$, Sata M. A retrospective case-control study of hepatitis $C$ virus infection and oral lichen planus in Japan: association study with mutations in the core and NS5A region of hepatitis $C$ virus. BMC Gastroenterology. 2012; 12: 31. doi:10.1186/1471230X-12-31.

33. Yu Z, Lu J, Jie L, et al. The Prevalence of hepatitis C virus infection in oral lichen planus in an Ethnic Chinese cohort of 232 patients. Int J Oral Sci. 2010; 2(2): 90-7.

34. Das A, Das J, Majumdar G, et al. No association between seropositivity for hepatitis $C$ virus and lichen planus: a case control study. Indian J Dermatol Venereol Leprol. 2006; 72: 198-200.

35. Khaja MN, Madhavi C, Thippavazzula R, et al. High prevalence of hepatitis $C$ virus infection and genotype distribution among general population, blood donors and risk groups. Infect Genet E. 2006; 6: 198-204.

\section{Correspondence to Heba F. Hassan E-mail: heba_micro08@yahoo.com Received $24^{\text {th }}$ Nov. 2015: Accepted $9^{\text {th }}$ Nov. 2016}

